Canadian

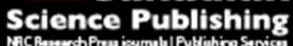

Canadian Journal of Microbiology Revue canadienne de de microbiologie

\title{
Effect of rotor type on the separation of isotope-labeled and unlabeled Escherichia coli RNA by isopycnic density ultracentrifugation
}

\begin{tabular}{|r|l|}
\hline Journal: & Canadian Journal of Microbiology \\
\hline Manuscript ID & cjm-2016-0483.R1 \\
\hline Danuscript Type: & Note \\
\hline Complete List of Authors: & $\begin{array}{l}\text { Herrmann, Elena; Furtwangen University, Faculty of Medical \& Life } \\
\text { Sciences, Institute of Precision Medicine } \\
\text { Koch, Patrick; Furtwangen University, Faculty of Medical \& Life Sciences, } \\
\text { Institute of Precision Medicine } \\
\text { Riedel, Christian U.; Ulm University, Institute of Microbiology and } \\
\text { Biotechnology } \\
\text { Young, Wayne; AgResearch Ltd., Grasslands Research Centre } \\
\text { Egert, Markus; Furtwangen University, Faculty of Medical \& Life Sciences, } \\
\text { Institute of Precision Medicine }\end{array}$ \\
\hline Keyword: & $\begin{array}{l}\text { RNA-SIP, ultracentrifugation, denaturation, near-vertical rotor, fixed-angle } \\
\text { rotor }\end{array}$ \\
\hline &
\end{tabular}




\section{Note}

\section{Effect of rotor type on the separation of isotope-labeled}

\section{and unlabeled Escherichia coli RNA by isopycnic density ultracentrifugation}

Elena Herrmann ${ }^{1}$, Patrick Koch ${ }^{1}$, Christian U. Riedel $^{2}$, Wayne Young ${ }^{3}$ and Markus Egert ${ }^{1}$ *

${ }^{1}$ Faculty of Medical and Life Sciences, Institute of Precision Medicine, Microbiology \& Hygiene Group, Furtwangen University, Campus Villingen-Schwenningen, Germany (Elena.Herrmann@hs-furtwangen.de; Patrick.Koch@gmx.net; Markus.Egert@hs-furtwangen.de)

${ }^{2}$ Institute of Microbiology and Biotechnology, University of Ulm, 89069 Ulm, Germany (Christian.Riedel@uni-ulm.de)

${ }^{3}$ AgResearch Ltd., Grasslands Research Centre, Palmerston North 4442, New Zealand (Wayne.Young@agresearch.co.nz)

\footnotetext{
*Correspondence: Faculty of Medical and Life Sciences, Institute of Precision Medicine, Microbiology \& Hygiene Group, Jakob-Kienzle-Str. 17, 78054 Villingen-Schwenningen, Germany; Phone: +49-7720-3074554; Fax: +49-7720-3074725; Email: Markus.Egert@hsfurtwangen.de
} 
Abstract: Separation of differentially isotope-labeled bacterial RNA by isopycnic density gradient centrifugation is a critical step in RNA-based stable isotope probing (RNASIP) analyses, which help to link the structure and function of complex microbial communities. Using isotope-labeled Escherichia coli RNA, we showed that an $8 \mathrm{~mL}$ nearvertical rotor performed better than a $2 \mathrm{~mL}$ fixed-angle rotor, thereby corroborating current recommendations. Neither increased concentrations of formamide nor urea in the medium improved the separation results using the fixed-angle rotor.

Keywords: RNA-SIP, ultracentrifugation, denaturation, near-vertical rotor, fixed-angle rotor 
Text: RNA-based stable isotope probing (RNA-SIP) is an innovative approach in microbial ecology to identify active microorganisms with particular physiological traits within a complex microbial community (Dumont and Murrell 2005; Whiteley et al. 2006). The principle of this culture-independent technique relies on a separation of isotope-labeled RNA from the abundant, unlabeled background RNA by isopycnic density gradient ultracentrifugation, thereby enabling comparative taxonomic analyses of the $16 \mathrm{~S}$ rRNA sequences present in the labeled 'heavy' and unlabeled 'light' nucleic acid fractions. $\left[{ }^{13} \mathrm{C}\right]-$ labeled sequences are mainly found in the 'heavy' gradient fractions and derive from metabolically active populations in the system which sequestered the $\left[{ }^{13} \mathrm{C}\right]$-label into their RNA, because they were able to ferment a specific isotope-labeled compound (Lueders et al. 2004; Radajewski et al. 2003; Whiteley et al. 2006). Thus, the efficiency of the separation of 'heavy' and 'light' RNA is crucial for successful resolution of the structure of the metabolically active community members in an RNA-SIP experiment (Lueders et al. 2004; Neufeld et al. 2007). Nevertheless, previous studies also reported that contamination of labeled RNA with unlabeled RNA molecules cannot be completely avoided (Lueders et al. 2004; Manefield et al. 2002). According to the literature (Whiteley et al. 2007), vertical rotors are most efficient at RNA separation while fixed-angle rotors are regarded second choice; swing-out rotors are not regarded as compatible with forming the required shallow isopycnic gradients.

Here, we compared the separation of $\left[{ }^{13} \mathrm{C}\right]$-labeled E. coli RNA from unlabeled background molecules by isopycnic density gradient centrifugation using two different types of ultracentrifugation rotors (a fixed-angle rotor and a near-vertical rotor). To the best of our knowledge, we present the first RNA-SIP-like study in which two rotor types were directly compared for their ability to separate isotope-labeled bacterial RNA. Our results confirmed that the vertical rotor was superior to the fixed-angle rotor in separating $\left[{ }^{13} \mathrm{C}\right]$-labeled RNA. 
Increased concentrations of urea and formamide, which denature RNA secondary structures, did not improve the separation effect of the fixed-angle rotor.

Isotope-labeled and unlabeled RNA was obtained from E. coli K12 cells grown in M9 minimal medium (Smith and Levine 1964) supplemented with thiamin $\left(2 \mathrm{mg} \mathrm{L}^{-1}\right)$, Casamino Acids (1 $\left.\mathrm{g} \mathrm{L}^{-1}\right)$ and $1 \mathrm{~g} \mathrm{~L} \mathrm{~L}^{-1}$ of either $\left[{ }^{12} \mathrm{C}\right]$ glucose (VWR, Darmstadt, Germany) or $\left[\mathrm{U}^{13} \mathrm{C}\right]$ glucose (Sigma-Aldrich, Darmstadt, Germany) as carbon source.

Total RNA was extracted from harvested cells using the FastRNA Pro Blue Kit (MP Biomedicals, Solon, Ohio) according to the manufacturer's protocol. Residual genomic DNA was removed by incubating the RNA $(100 \mu \mathrm{l})$ for $1 \mathrm{~h}$ at $37^{\circ} \mathrm{C}$ with $10 \mu \mathrm{l}$ Rase-free DNase I

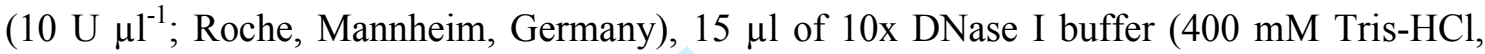
$100 \mathrm{mM} \mathrm{NaCl}, 60 \mathrm{mM} \mathrm{MgCl} 2,10 \mathrm{mM} \mathrm{CaCl}_{2}, \mathrm{pH}$ 7.9.) and $25 \mu$ of nuclease-free water. Further purification was performed using Qiagen RNeasy spin columns (Qiagen, Hilden, Germany) according to the manufacturer's instructions. After elution, RNA samples were quantified using a P360 Nanophotometer (Implen GmbH, Munich, Germany) and integrity was checked by standard agarose gel electrophoresis. Absence of genomic DNA was verified by PCR targeting the 16S rRNA genes using universal bacterial primers. For the experiments, either $\left[{ }^{12} \mathrm{C}\right] \mathrm{RNA},\left[{ }^{13} \mathrm{C}\right] \mathrm{RNA}$ or a 1:1 mixture of $\left[{ }^{12} \mathrm{C}\right] \mathrm{RNA}$ and $\left[{ }^{13} \mathrm{C}\right] \mathrm{RNA}$ was used.

Density gradient ultracentrifugation was performed following a previously described RNA-SIP protocol (Egert et al. 2007) with the following adjustments: centrifugation was performed using either an MLA-130 rotor (fixed-angle rotor, $35^{\circ}$ angle) with $2 \mathrm{~mL}$ QuickSeal Polypropylene tubes or an MLN-80 rotor (near-vertical rotor, $9^{\circ}$ angle) with $8 \mathrm{~mL}$ Quick-Seal Polypropylene tubes (all rotors and centrifugation tubes Beckman Coulter, Krefeld, Germany). The centrifugation medium for the $2 \mathrm{~mL}$ or $8 \mathrm{~mL}$ bell top ultracentrifugation tubes was prepared by mixing cesium trifluoroacetate (CsTFA) stock solution [1.570 mL or $6.660 \mathrm{~mL}$, respectively; $2 \mathrm{~g} \mathrm{~mL}^{-1}$, GE Healthcare, Freiburg, Germany] 
and gradient buffer [0.349 mL or $1.480 \mathrm{~mL}$; (Lueders et al. 2004)] containing 200 ng or $\sim 840 \mathrm{ng}$ of E. coli RNA and formamide [0.061 mL or $0.260 \mathrm{~mL}$; Roth, Karlsruhe, Germany]. Thus, the effective RNA concentration was $\sim 100 \mathrm{ng} \mathrm{mL}^{-1}$ for each rotor type. Prior to centrifugation, the density of each solution was measured refractometrically and adjusted to similar buoyant densities $\left(\sim 1.79 \mathrm{~g} \mathrm{~mL}^{-1}\right)$ by adding small quantities of CsTFA stock solution or gradient buffer (Egert et al. 2007). Gradients were centrifuged at 120,000 x g (44,600 rpm; MLA-130) and 123,100 x g (45,000 rpm, MLN-80), for $\sim 48 \mathrm{~h}$ and $20^{\circ} \mathrm{C}$ in an Optima MAXXP Ultracentrifuge (Beckman Coulter). Afterwards, 15 equal fractions $(\sim 130 \mu \mathrm{l})$ for the $2 \mathrm{~mL}$ tubes or 16 equal fractions $(\sim 500 \mu \mathrm{l})$ for the $8 \mathrm{~mL}$ tubes were collected from bottom to top of the centrifugation tubes by displacing the gradient medium with water using a syringe pump. Subsequently, the refractive index of each gradient fraction was determined and correlated to its density by means of a previously established calibration curve between refractive index and density. RNA was precipitated, washed with ethanol, eluted in $20 \mu \mathrm{L}$ nuclease-free water and quantified with a RiboGreen low range assay (Life Technologies GmbH, Darmstadt, Germany) (Egert et al. 2007).

Similar shallow density gradients were obtained with both rotor types (Figs. 1A and 2A). These gradients were also similar to previously published gradients from RNA-SIP studies (Egert et al. 2007; Kovatcheva-Datchary et al. 2009; Young et al. 2015).

Using the MLA-130 fixed-angle rotor, the concentration of unlabeled $\left[{ }^{12} \mathrm{C}\right] \mathrm{RNA}$ peaked in fraction 8 , i.e. at a density of $\sim 1.79 \mathrm{~g} \mathrm{~mL}^{-1}$, while labeled $\left[{ }^{13} \mathrm{C}\right] \mathrm{RNA}$ peaked in fraction 4 at a density of $\sim 1.82 \mathrm{~g} \mathrm{~mL}^{-1}$. However, when a mix of $\left[{ }^{12} \mathrm{C}\right] \mathrm{RNA}$ and $\left[{ }^{13} \mathrm{C}\right] \mathrm{RNA}$ (1:1 ratio) was subjected to ultracentrifugation in the MLA-130 fixed-angle rotor, no clear separation of labeled and unlabeled RNA was observed, and the RNA concentration peaked in fraction 6 at an intermediate density (Fig. 1B). Such incomplete separation might be caused by RNA secondary structures (Lueders et al. 2004; Manefield et al. 2002). However, even the use of $3.1 \%(\mathrm{v} / \mathrm{v})$ denaturing formamide to resolve these secondary structures as 5 
recommended previously (Lueders et al. 2004) could not alleviate this artifact. Also increasing the formamide concentration up to $18.8 \%$ or the use of $1 \mathrm{M}$ of urea in the gradient solution as an optional RNA denaturing agent (Lambert and Draper 2012) did not improve the separation efficiency (data not shown). By contrast, the use of such high concentrations of formamide and urea led to abnormal RNA banding patterns, although the linearity of the gradients was still obtained (data not shown).

Similar to the fixed-angle rotor, ultracentrifugation of RNA with the MLN-80 nearvertical rotor resulted in accumulation of the bulk of labeled $\left[{ }^{13} \mathrm{C}\right] \mathrm{RNA}$ in fraction 6 at a density of $\sim 1.81 \mathrm{~g} \mathrm{~mL}^{-1}$ and unlabeled $\left[{ }^{12} \mathrm{C}\right] \mathrm{RNA}$ in fraction 10 at $\sim 1.79 \mathrm{~g} \mathrm{~mL}^{-1}$, respectively, when centrifuged separately. However, the use of a 1:1 mixture of labeled and unlabeled RNA resulted in a clear separation pattern with two distinct peaks of maximum RNA concentrations at the same densities as the separately centrifuged RNA species (Fig. 2B).

In our study, most efficient separation of a 1:1 mixture of isotope-labeled and unlabeled E. coli RNA could reproducibly be achieved by using the near-vertical MLN-80 rotor. Despite the presence of formamide in the centrifugation gradients to release RNA secondary structure, the use of a fixed-angle rotor led to incomplete resolution of unlabeled $\left[{ }^{12} \mathrm{C}\right] \mathrm{RNA}$ and labeled $\left[{ }^{13} \mathrm{C}\right] \mathrm{RNA}$. Our study thereby clearly corroborates the strong recommendation of vertical rotors for RNA-SIP studies (Whiteley et al. 2007).

The observed enhanced RNA separation power of the vertical rotor is most likely based on the angle of inclination and the geometry of the rotor (Adam et al. 2009; Holtzhauer 2006). Through reorientation of the gradient during centrifugation, near-vertical rotors are characterized by a reduced path length for sedimentation $\left(r_{\max }-r_{\min }\right)$ compared to fixed-angle rotors (Fig. 3). Along this path length, the difference in g-force is smaller as the g-force increases with increasing radius. This leads to shallower density gradients in near-vertical rotors. Shallow density gradients are particularly suitable for RNA-SIP analyses, where the mass differences between labeled and unlabeled RNA molecules are usually rather subtle 
(Lueders et al. 2004; Manefield et al. 2002). However, under the centrifugation conditions applied here, both rotor types yielded very similar and shallow density gradients (Figs. 1A and $2 \mathrm{~A})$.

Notably, in a near-vertical rotor, the RNA molecules distribute over an extended area, which might result in less RNA interactions and hence lead to a better isopycnic density resolution (Adam et al. 2009). The separation of nucleic acids during ultracentrifugation is also dependent on the total volume of gradient solution that separates isopycnic sample zones after the run. As a result of the geometry of the rotor, vertical and near-vertical rotors show the largest volume of gradient solution between isopycnic zones of banding nucleic acid (Griffith 2007). We accounted for the different volumes (2 mL vs. $8 \mathrm{~mL}$ ) of the centrifugation tubes by normalizing the RNA concentration to $100 \mathrm{ng} \mathrm{mL}^{-1}$ in all experiments, however, the above-mentioned effects might have been increased by the fact that the height-to-diameter ratio of the $8 \mathrm{~mL}$ tubes for the near-vertical rotor was $3.6(57 \times 16 \mathrm{~mm})$, while it was just 2.9 $(32 \times 11 \mathrm{~mm})$ for the $2 \mathrm{~mL}$ tubes of the fixed-angle rotor.

We conclude that (near-) vertical rotors and tubes with a larger height-to-diameter ratio are more suitable for RNA-SIP studies than fixed-angle rotor and tubes with a lower height-to-diameter ratio.

\section{Acknowledgments}

This study was funded by the "Innovative / Cooperative Projects" program of the German federal state of Baden-Württemberg (Project Präbio-SIP).

\section{References}

Adam, G., Läuger, P., and Stark, G. 2009. Physikalische Chemie und Biophysik. $5^{\text {th }}$ ed. [in German], Springer, Heidelberg, Germany.

Dumont, M.G., and Murrell, J.C. 2005. Stable isotope probing - linking microbial identity to 
function. Nat. Rev. Microbiol. 3(6): 499-504.

Egert, M., de Graaf, A.A., Maathuis, A., de Waard, P., Plugge, C.M., Smidt, H., Deutz, N.E., Dijkema, C., de Vos, W.M., and Venema, K. 2007. Identification of glucosefermenting bacteria present in an in vitro model of the human intestine by RNA-stable isotope probing. FEMS Microbiol. Ecol. 60(1): 126-135.

Griffith, O.M. 2007. Density gradient separations in vertical tube, near vertical tube, fixed angle, and swining bucket rotors: A comparative study. Available from http://www.americanlaboratory.com/914-Application-Notes/19002-Density-GradientSeparations-in-Vertical-Tube-Near-Vertical-Tube-Fixed-Angle-and-Swinging-BucketRotors-A-Comparative-Study/ [accessed 9 August 2016].

Holtzhauer, M. 2006. Basic Methods for the Biochemical Lab. $1^{\text {st }}$ ed., Springer, Berlin, Germany.

Kovatcheva-Datchary, P., Egert, M., Maathuis, A., Rajilic-Stojanovic, M., de Graaf, A.A., Smidt, H., de Vos, W.M., and Venema, K. 2009. Linking phylogenetic identities of bacteria to starch fermentation in an in vitro model of the large intestine by RNAbased stable isotope probing. Environ. Microbiol. 11(4): 914-926.

Lambert, D., and Draper, D.E. 2012. Denaturation of RNA secondary and tertiary structure by urea: simple unfolded state models and free energy parameters account for measured m-values. Biochemistry 51(44): 9014-9026.

Lueders, T., Manefield, M., and Friedrich, M.W. 2004. Enhanced sensitivity of DNA- and rRNA-based stable isotope probing by fractionation and quantitative analysis of isopycnic centrifugation gradients. Environ. Microbiol. 6(1): 73-78.

Manefield, M., Whiteley, A.S., Ostle, N., Ineson, P., and Bailey, M.J. 2002. Technical considerations for RNA-based stable isotope probing: an approach to associating microbial diversity with microbial community function. Rapid Commun. Mass Spectrom. 16(23): 2179-2183. 
Neufeld, J.D., Dumont, M.G., Vohra, J., and Murrell, J.C. 2007. Methodological considerations for the use of stable isotope probing in microbial ecology. Microb. Ecol. 53(3): 435-442.

Radajewski, S., McDonald, I.R., and Murrell, J.C. 2003. Stable-isotope probing of nucleic acids: a window to the function of uncultured microorganisms. Curr. Opin. Biotechnol. 14(3): 296-302.

Smith, H.O., and Levine, M. 1964. Two sequential repressions of DNA synthesis in the establishment of lysogeny by phage P22 and its mutants. Proc. Natl. Acad. Sci. U.S.A. 52: 356-363.

Whiteley, A.S., Manefield, M., and Lueders, T. 2006. Unlocking the 'microbial black box' using RNA-based stable isotope probing technologies. Curr. Opin. Biotechnol. 17(1): $67-71$.

Whiteley, A.S., Thomson, B., Lueders, T., and Manefield, M. 2007. RNA stable-isotope probing. Nat. Protoc. 2(4): 838-844.

Young, W., Egert, M., Bassett, S.A., and Bibiloni, R. 2015. Detection of sialic acid-utilising bacteria in a caecal community batch culture using RNA-based stable isotope probing. Nutrients 7(4): 2109-2124. 


\section{Figure captions}

Fig. 1. Density gradients prepared with the MLA-130 fixed-angle rotor.

(A) Density of gradient fractions averaged over 3 independent gradients. (B) Representative, density-dependent RNA concentration in gradient fractions. RNA was isolated from E. coli $\mathrm{K} 12$ grown with either $\left[{ }^{12} \mathrm{C}\right]$ glucose or $\left[\mathrm{U}^{13} \mathrm{C}\right]$ glucose. Values are given in relative units $(\%$; fraction with the highest RNA concentration per gradient was set at $100 \%$ ) to facilitate comparison between the gradients (Egert et al. 2007).

Fig. 2. Density gradients prepared with the MLN-80 near-vertical rotor.

(A) Density of gradient fractions averaged over 3 independent gradients. (B) Representative, density-dependent RNA concentration in gradient fractions. RNA was isolated from E. coli $\mathrm{K} 12$ grown with either $\left[{ }^{12} \mathrm{C}\right]$ glucose or $\left[\mathrm{U}^{13} \mathrm{C}\right]$ glucose. Values are given in relative units $(\%$; fraction with the highest RNA concentration per gradient was set at $100 \%$ ) to facilitate comparison between the gradients (Egert et al. 2007).

Fig. 3. Schematic illustration of density gradient ultracentrifugation in two rotor types.

(A) Fixed-angle rotor (MLA-130), (B) Near-vertical rotor (MLN-80). For both, the position of isopycnically banding RNA molecules during centrifugation in a cesium trifluoroacetate (CsTFA) gradient is shown. $r_{\min }$ describes the position of the meniscus during centrifugation, $r_{\max }$ the distal end of the centrifugation tube. 

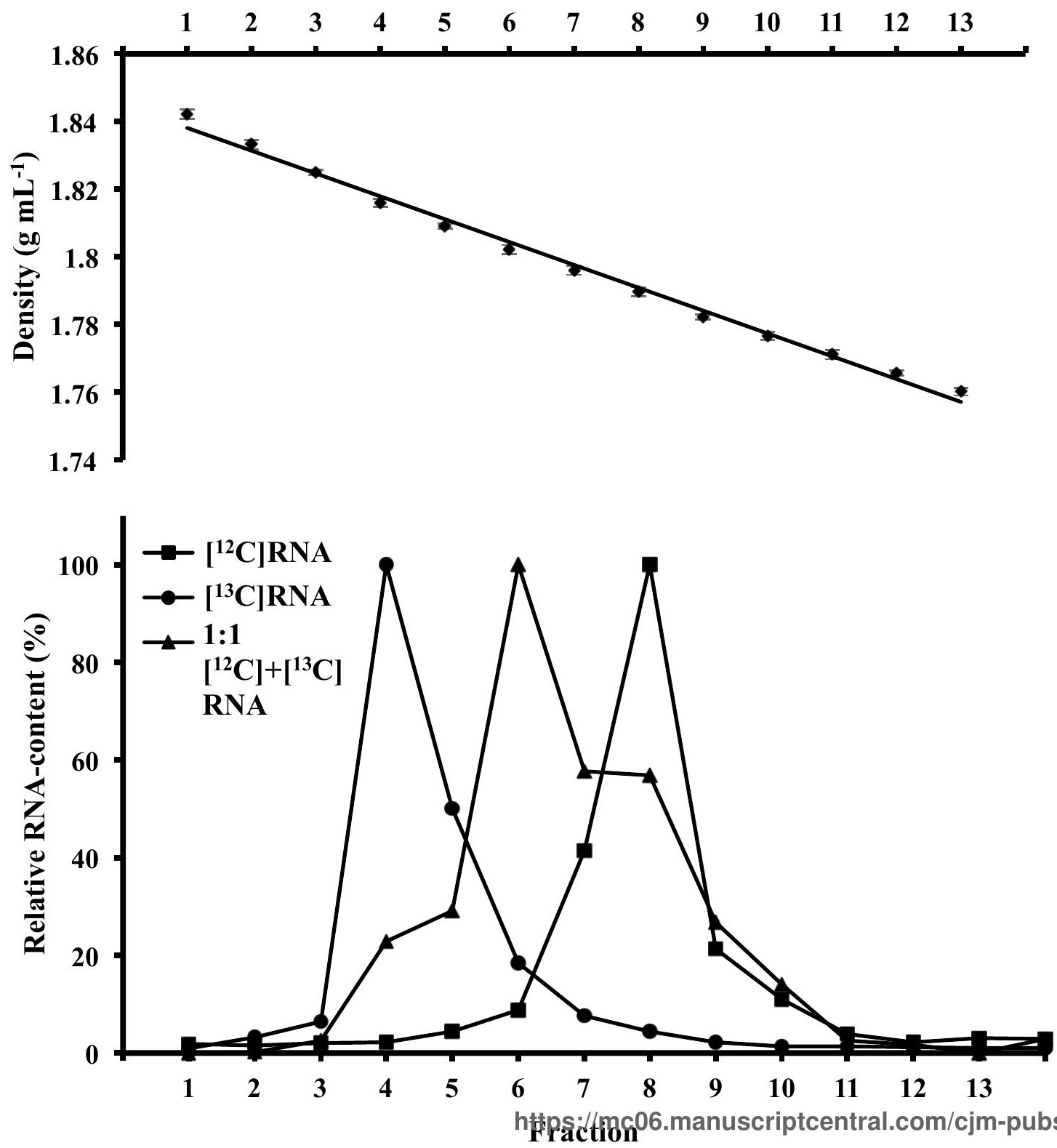

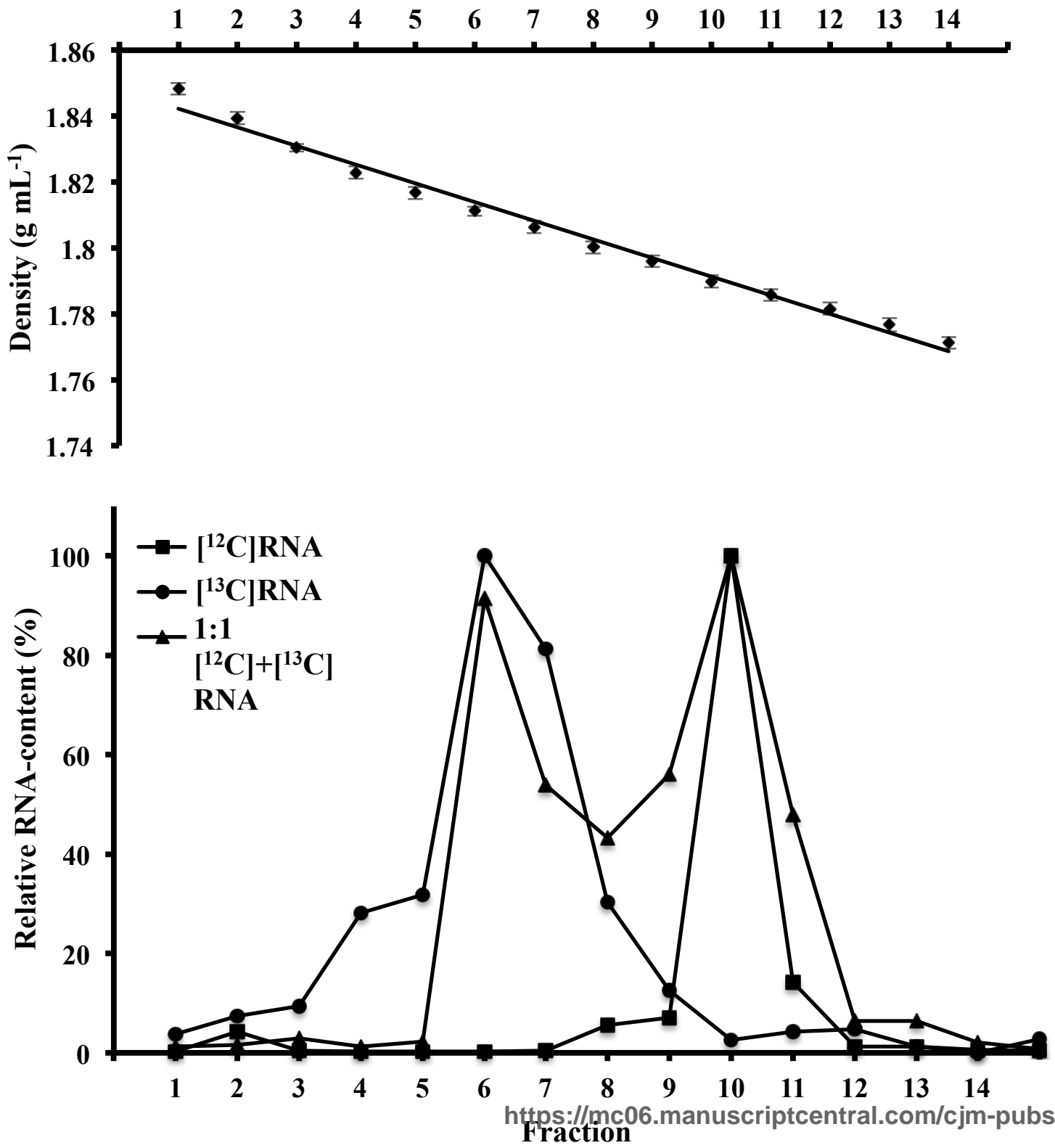


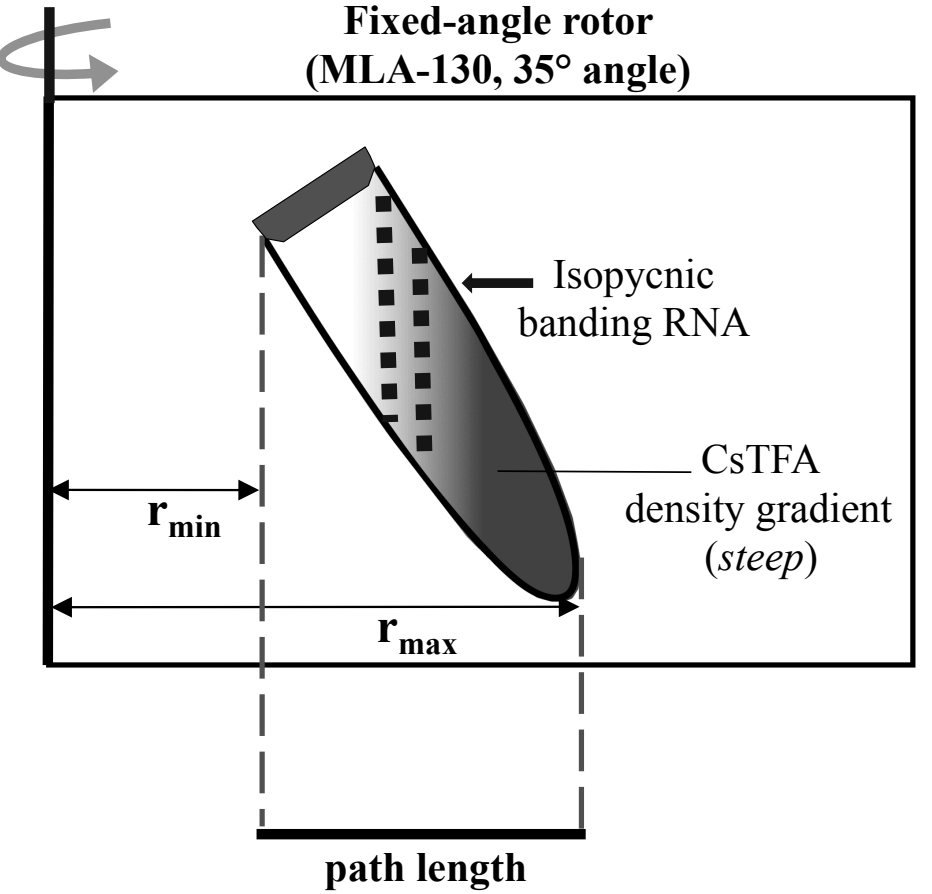

during centrifugation



during centrifugation 